\title{
Analisis Perbandingan Nilai Koordinat Wall Station Sebagai Titik Kontrol Posisi Tambang Bawah Tanah dengan Pengamatan Poligon Tertutup dan Pengikatan Ke belakang (Studi Kasus: Tujuh Bukit Underground Project, PT. Bumi Suksesindo)
}

\author{
Comparative Analysis of Wall Station Coordinate Value as a Control Point of Underground Mining Position with \\ Closed Polygon Observation and Resection Method \\ (Case Study: Tujuh Bukit Underground Project, PT. Bumi Suksesindo)
}

\author{
Doni Muslim Cahya ${ }^{1}$, Yuwono*2, Akbar Kurniawan*3 \\ ${ }^{1,2,3}$ Departemen Teknik Geomatika, FTSLK-ITS, Kampus ITS Sukolilo, Surabaya, 60111, Indonesia \\ *Korespondensi penulis: yuwono@geodesy.its.ac.id ${ }^{2}$, akbar@geodesy.its.ac.id ${ }^{3}$
}

Diterima : 14082020; Diperbaiki : 04092020; Disetujui : 09092020; Dipublikasi : 21012021

\begin{abstract}
Abstrak: Proses penggalian pada area pertambangan menyebabkan perubahan topografi secara terus menerus. Oleh karena itu diperlukan pengukuran yang berkala untuk memastikan ketersedian data topografi. Dalam pengamatan posisi di bawah tanah, penentuan titik kontrol dan detil situasi adalah kunci dari kegiatan survei topografi. Penggunaan metode Wall Station memiliki kestabilan posisi yang cukup baik karena bertempat pada dinding Decline, dan pada metode ini alat ukur tidak dapat berdiri pada titik Wall Station dan harus menggunakan metode yang lain untuk perhitungan koordinat. PT. Bumi Suksesindo merupakan perusahaan pertambangan Penanaman Modal Dalam Negeri (PMDN) dengan konsesi utama di Tujuh Bukit Operation. Dalam pengelolaan minesite, PT. Bumi Suksesindo menggunakan metode Undeground Project. Dimana penentuan posisi dan pendapatan titik kontrol, dilakukan dengan metode Pengikatan Ke belakang, dengan menggunakan bantuan alat Total Station dan Wall Station. Kegiatan pengamatan titik kontrol ini dilakukan pada 6 titik Wall Station yang berada didalam tambang bawah tanah yaitu Wall Station DC1 18, 20 25, 42, 46, dan 48. Pengamatan ini akan dibandingkan dengan koordinat acuan yang telah dikoreksi oleh pihak PT. Bumi Suksesindo untuk menghasilkan nilai koreksi secara rutin. Pada penelitian ini menghasilkan nilai selisih dan RMSE pada masing masing titik Wall Station. Metode pengamatan pengukuran poligon tertutup dengan perhitungan Kuadrat Terkecil pada Poligon Box Cut menghasilkan nilai selisih koordinat dan RMSE pada Wall Station DC1-18 dengan nilai error 0,00031 m, DC1-20 dengan nilai error 0,00144 m, DC1-25 dengan nilai error 0,00113 m, DC1-42 dengan nilai error 0,00315 m, DC1-46 dengan nilai error 0,00320 m, DC1-48 dengan nilai error 0,00288 m.
\end{abstract}

Copyright $@ 2020$ Geoid. All rights reserved

\begin{abstract}
The excavation process in the mining area causes continuous topographic changes. Therefore, periodic measurements are needed to ensure the availability of topographic data. In observing the position below the ground, determining the control point and the details of the situation is the key to the topographic survey activities. The use of the Wall Station method has a fairly good position stability because it is located on the Decline wall, and in this method the measuring instrument cannot stand on the Wall Station point and must use another method for calculating coordinates. PT. Bumi Suksesindo is a Domestic Investment (PMDN) mining company with the main concession in the Tujuh Bukit Operation. In managing minesite, PT. Bumi Suksesindo uses the Underground Project method. Where the determination of the position and income of control points, is carried out by Resection method, using the help of Total Station and Wall Station tools. This control point observation activity will be carried out at 6 Wall Station points inside the underground mine, namely DC1 18, 20 25, 42, 46, and 48 Wall Station. These observations will be compared with the reference coordinates corrected by PT. Bumi Suksesindo to produce corrected values routinely. This research produces the difference value and RMSE at each Wall Station point. The observation method using closed polygons with the calculation of least squares on the box cut polygons results in the difference between the coordinates and the RMSE. Wall Station DC1-18 resulted an error value of $0.00031 \mathrm{~m}, \mathrm{DC1}-20$ with an error value of $0.00144 \mathrm{~m}, \mathrm{DC} 1$ 25 with an error value of 0, $00113 \mathrm{~m}, \mathrm{DC1}-42$ with an error value of 0.00315 m, DC1-46 with an error value of $0.00320 \mathrm{~m}, \mathrm{DC1}-48$ with an error value of $0.00288 \mathrm{~m}$.
\end{abstract}

Kata kunci : Tambang Bawah Tanah; Wall Station; Poligon Tertutup; Pengikatan Kebelakang; RMSE 


\section{Pendahuluan}

Pertambangan terdiri dari beberapa tahapan, salah satunya yaitu tahap ekploitasi. Eksploitasi pertambangan secara umum dibagi menjadi 2 jenis yaitu tambang terbuka (Open Pit) dan tambang bawah tanah (Underground Mine). Eksploitasi adalah segala bentuk upaya atau kegiatan yang dilakukan untuk mengambil sumber daya potensi yang terdapat pada wilayah tersebut. Pada pertambangan, eksploitasi dilakukan untuk mendapatkan hasil tambang, karena proses penggalian ini pada area pertambangan selalu terjadi perubahan topografi. Perubahan ini berlangsung terus - menerus seiring dengan berjalannya eksploitasi. Oleh karena itu diperlukan pengukuran yang berkala untuk memastikan ketersedian data topografi tersebut. Dalam memperoleh data topografi, dilakukan kegiatan survei pemetaan topografi, Survei topografi merupakan pemetaan permukaan bumi fisik dan kenampakan hasil budaya manusia (Basuki 2011), yang merupakan pekerjaan utama dalam tambang bawah tanah. Kegiatan eksploitasi dan eksplorasi dilakukan di bawah tanah, sehingga diperlukan data topografi bawah tanah untuk membantu keberlangsungan kegiatan pertambangan.

PT. Bumi Suksesindo merupakan suatu perusahaan pertambangan Penanaman Modal Dalam Negeri (PMDN) dengan konsesi utama di Tujuh Bukit Operation. Dalam pengelolaan minesite, PT. Bumi Suksesindo menggunakan metode Undeground Project / tambang bawah tanah. Yang dimana penentuan posisi dan pendapatan titik kontrol, dilakukan dengan metode Pengikatan Kebelakang, dengan menggunakan bantuan alat Total Station dan Wall Station. Kegiatan pengamatan titik kontrol ini akan dilakukan dengan koreksi secara rutin dengan menggunakan metode poligon kecil (dari titik kontrol sebelumnya ke kontrol titik yang baru) hal ini dikarenakan kegiatan validasi ini dilakukan untuk efisiensi kegiatan dan waktu yang dibutuhkan, oleh karena itu diperlukan pengamatan poligon besar (Satu kali Loop dari titik kontrol utama hingga titik kontrol yang baru). Kegiatan pengamatan titik kontrol dengan menggunakan poligon besar dilakukan untuk mengurangi kesalahan pengamatan yang dilakukan oleh pengukuran poligon kecil dan metode pengikatan kebelakang

Metode pengikatan ke belakang dilakukan dengan mendapatkan satu titik yang tidak diketahui koordinatnya dari tiga titik kontrol yang telah diketahui koordinatnya. Pada pengukuran poligon tertutup dilakukan penentuan posisi suatu titik dari titik yang diketahui dan kembali ke titik tersebut. Oleh karena itu hasil koordinat posisi dari metode pengikatan ke belakang ini akan dibandingkan dengan hasil pengukuran poligon yang akan memperoleh perbandingan kesalahan dan perbedaan antara kedua metode tersebut.

Penelitian ini merupakan penelitian pertama dalam pengamatan titik kontrol Wall Station yang ada di tambang bawah tanah dengan menggunakan 2 metode pengamatan yaitu poligon tertutup dan pengikatan kebelakang. Pada bagian bab ini berisikan penelitian yang serupa atau penjelasan lebih lanjut mengenai pembahasan yang terkait pada pengamatan dan perhitungan penelitian ini.

\section{Data dan Metode}

Data yang digunakan dalam penelitian ini adalah Data hasil pekerjaan tambang di salah satu Pit pada area tambang PT Anugerah Bara Kaltim, dimana data diambil dengan menggunakan Total Station Sokkia Set 2X. Data berupa koordinat detail $(\mathrm{X}, \mathrm{Y}, \mathrm{Z})$ dan koordinat $(\mathrm{X}, \mathrm{Y}, \mathrm{Z})$ alignment atau baseline (sebagai acuan perhitungan volume metode trapezoidal). Peralatan yang digunakan adalah perangkat lunak dan perangkat keras. Perangkat lunak yang digunakan adalah AutoCAD Civil 3D dan Matlab. Perangkat keras terdiri dari laptop dan mouse.

Lokasi penelitian ini dilaksanakan pada Tujuh Bukit Underground Project pada PT. Bumi Suksesindo. Secara

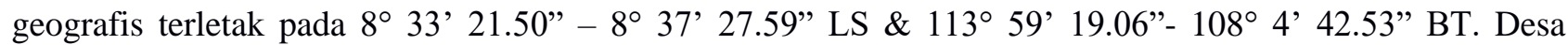
Sumberagung, Kecamatan Pesanggaraan, Kabupaten Banyuwangi, Provinsi Jawa Timur, Indonesia. Dengan koordinat jarak antara daerah penambangan dengan Kota Banyuwangi $\pm 70 \mathrm{~km}$ dengan waktu tempuh $\pm 2-3$ jam. Untuk lokasi titik poligon dan lokasi pengamatan penlitian berada di pit underground Project/ Decline Project yang merupakan projek pertambangan bawah tanah yang ada di PT. Bumi Suksesindo. 


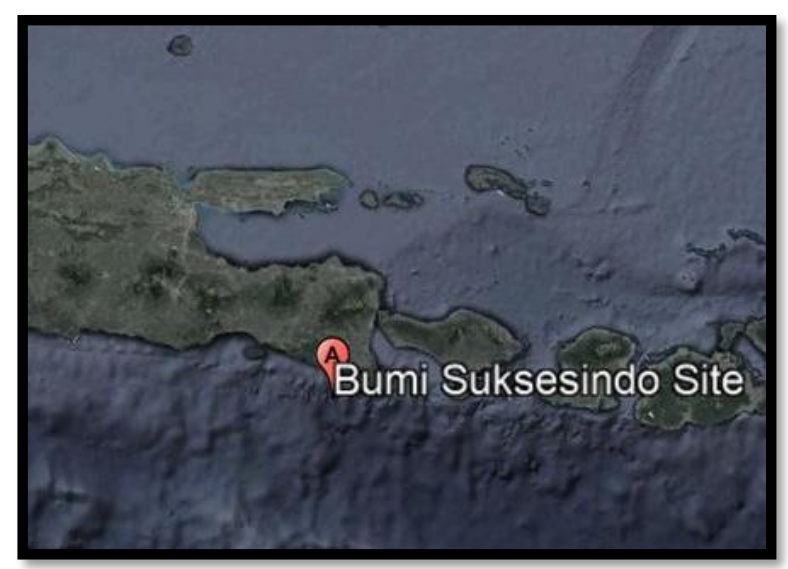

Gambar 1. Lokasi Penelitian (website PT. Bumi Suksesindo)

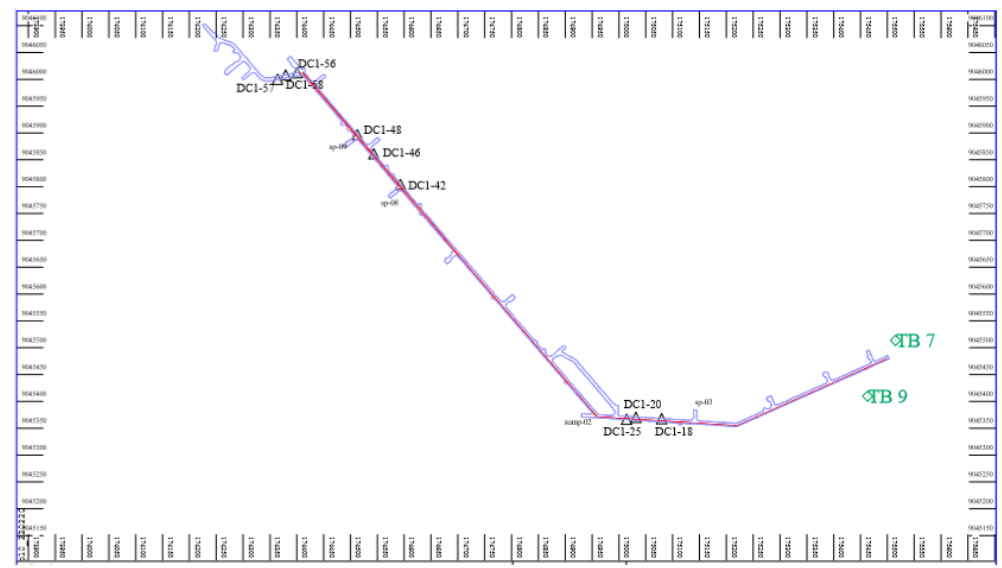

Gambar 2. Driive Exploration Pt. Bumi Suksesindo

Pada penelitian ini, dibutuhkan beberapa data untuk menunjang pelaksanaan penelitian. Berikut adalah data yang dibutuhkan dalam penelitian ini:

a. Data Titik Kontrol Wall Station, point DC1-18, 20, 25, 42, 46, 48, sebagai data acuan.

b. Data koordinat titik ikat koordinat Box Cut TB 7 dan TB 9

c. Data primer pengukuran Poligon dan pengamatan titik Wall Station.

d. Data sekunder pengukuran poligon dengan pengamatanWall Station pada tahun tahun sebelumnya.

e. Data Pengukuran dengan metode Pengikatan Kebelakang

Ada beberapa peralatan yang dibutuhkan dalam penelitian ini, baik software maupun hardware adalah sebagai berikut:
a. Total Stasion Leica TS15
b. Total Station Leica TS16
c. Prisma Poligon Leica
d. Statif
e. Prisma Wall Station Leica
f. Microsoft Excel
g. Surpac 10.6

Titik Wall Station dipilih pada tititk point DC1-18, 20, 25, 42, 46, 48. Yang berada pada jalur Drive Exploration pada tambang bawah tanah di PT. Bumi suksesindo, Banyuwamgi, Jawa Timur. Pemilihan titik titik ini dilakukan dengan titik titik sbeelumnya yang merupakan titik koordinat yang sering digunakan dalam penagmatan dan koreksi titik di PT. Bumi Suksesindo. 
Pada perhitungan koordinat Wall Station dengan pengamatan Poligon tertutup dilakukan dengan menggunakan perhitungan perataan Kuadrat terkecil Least Square dengan koordinat pendekatan dengan menggunakan metode Bowditch, dan pada pengamatan pengikatan kebelakang dilakukan perhitungan dengan metode Cllins dan dilakukan pertaan dengan Least Square pada perhitungan pengikatan kebelakang.

Pada pengamatan dengan metode Poligon Tertutup dilakukan dengan mengguanakan perhitunagan Bowditch, dengan perhitungan rumuse berikut:

Syarat penutup sudut (sudut luar)

$\Sigma \beta=(\mathrm{n}+2) 180^{\circ}$

Koreksi sudut (sudut luar)

$\Sigma \beta=(\mathrm{n}+2) 180^{\circ}+\mathrm{f} \beta$

$\alpha_{\mathrm{nn}}=\alpha_{\mathrm{nn}+1} \pm 180^{\circ} \pm \beta$,

Keterangan:

$\alpha_{\mathrm{n}} \quad=$ Azimuth dari $\mathrm{n}$ ke $\mathrm{n}$

$\alpha_{n+1} \quad=$ Azimuth dari $n$ ke $n+1$

$\beta$, $\quad=$ Sudut $\beta$ terkoreksi

Selisih absis:

$(\Delta x)=d \sin \alpha$

Selisih ordinat:

$(\Delta y)=d \cos \alpha$

$\left(\Delta \boldsymbol{x}^{\prime}\right)=\Delta \boldsymbol{x}-\left(\left(\frac{d}{\sum \mathrm{d}}\right) \cdot f x\right)$

$\left(\Delta \mathrm{y}^{\prime}\right)=\Delta \mathrm{y}-\left(\left(\frac{d}{\sum \mathrm{d}}\right) \cdot f y\right)$

Keterangan:

$\mathrm{d}=$ Jarak antara 2 titik

$\sum \mathrm{d}=$ Jumlah jarak poligon

$\mathrm{fx} \quad=$ Jumlah selisih absis

fy $\quad=$ Jumlah selisih ordinat

$\mathrm{X}_{\mathrm{n}}=\mathrm{X}+\Delta \mathrm{x}$

$\mathrm{Y}_{\mathrm{n}}=\mathrm{Y}+\Delta \mathrm{y}^{\prime}$

Keterangan:

$\mathrm{X}_{\mathrm{n}} \quad=$ Absis yang dicari

$\mathrm{X}=$ Absis yang diketahui

$\mathrm{Y}_{\mathrm{n}} \quad=$ Absis yang dicari

$\mathrm{Y} \quad=$ Ordinat yang diketahui

$\Delta \mathrm{x} \quad=$ Selisih Absis

$\Delta \mathrm{y} \quad=$ Selisih Ordinat 
Toleransi pengukuran sudut (Nurjati 2004):

$\mathbf{f} \beta \leq \mathbf{i} \sqrt{ } \mathbf{n}$

Keterangan:

$\mathrm{f} \beta=$ Salah penutup sudut

$\mathrm{i}=$ Bacaan ketelitian alat

$\mathrm{n} \quad=$ Jumlah titik poligon

Toleransi pengukuran jarak:

$\frac{\sqrt{ } \mathbf{f x}^{2}+\mathbf{f y}^{2}}{\sum \mathbf{d}} \leq \frac{1}{\mathbf{2 0 0 0 0}}$

Keterangan:

$\sqrt{ } \mathrm{fx}^{2}+\mathrm{fy}^{2}=$ Kesalahan linier

$\Sigma \mathrm{d}=$ Jumlah jarak antar titik sudut

Pada pengamatan poligon tertutup juga dilakukan dengan perhitungan Square, dan dengan menggunakan model matematika berikut:

$\mathrm{V}=\mathrm{AX}-\mathrm{F}$

Dalam hal ini:

$\mathrm{V} \quad$ : Matriks vektor residu pengamatan $\left(V_{1}, V_{2}, V_{3}, \ldots, V n\right)$, dimensi matriksnya (nx1)

A : matriks desain yang elemennya merupakan turunan pertama ukuran terhadap parameter, dimensi matriks A yaitu (nxu)

$\mathrm{X} \quad$ : matriks parameter dengan dimensi (nx1)

F : matriks sisa pengurangan nilai pendekatan dengan ukuran $(\mathrm{nx} 1)$

Linearisasi Jarak

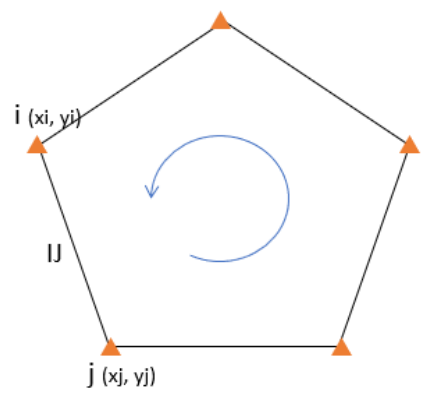

Gambar 3. Linearisasi sudut

$\begin{array}{ll}\mathrm{dxi}=\frac{X i-X j}{I J} & ; \text { dyi }=\frac{Y i-Y j}{I J} \\ \mathrm{dxj}=\frac{X j-X i}{I J} & ; \mathrm{dyj}=\frac{Y j-Y i}{I J}\end{array}$

Keterangan:

$\mathrm{dxi}=$ Lineraisi parameter $\mathrm{x}$ pada posisi berdiri alat

dyi $=$ Lineraisi parameter y pada posisi berdiri alat

$\mathrm{dxi}=$ Lineraisi parameter $\mathrm{x}$ pada posisi target

dyi $=$ Lineraisi parameter y pada posisi target

$\mathrm{Xi}=$ Koordinat $\mathrm{x}$ titik posisi berdiri alat 
$\mathrm{Yi}=$ Koordinat y titik posisi berdiri alat

$\mathrm{Xj}=$ Koordinat $\mathrm{x}$ titik posisi target

$\mathrm{Yj}=$ Koordinat $\mathrm{y}$ titik posisi target

$\mathrm{IJ}=$ jarak antara posisi alat dan target

Linearisasi sudut

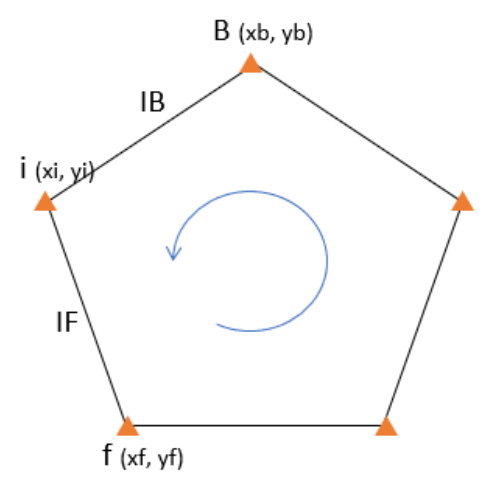

Gambar 4. Linearisasi Sudut polygon

$$
\begin{aligned}
\mathrm{dx}_{\mathrm{f}}=\frac{Y f-Y i}{I F^{2}} ; & \mathrm{dyf}=\frac{X f-X i}{I F^{2}} \\
\mathrm{dx}_{\mathrm{b}}=\frac{Y i-Y b}{I B^{2}} \quad ; & \mathrm{dyi}=\frac{X i-X b}{I B^{2}} \\
\mathrm{dx}_{\mathrm{i}}=\frac{Y b-Y i}{I B^{2}}-\frac{Y f-Y i}{I F^{2}} & ; \mathrm{dyi}=\frac{X i-X b}{I B^{2}}-\frac{X i-X f}{I F^{2}}
\end{aligned}
$$

Keterangan:

$\mathrm{dxf}=$ Lineraisi parameter $\mathrm{x}$ pada posisi berdiri alat

dyf $=$ Lineraisi parameter y pada posisi berdiri alat

$\mathrm{dxb}=$ Lineraisi parameter $\mathrm{x}$ pada posisi target backsight

dyb $=$ Lineraisi parameter y pada posisi target backsight

$\mathrm{dxf}=$ Lineraisi parameter $\mathrm{x}$ pada posisi berdiri alat forsight

dyf $=$ Lineraisi parameter y pada posisi berdiri alat forsight

$\mathrm{Xi}=$ Koordinat $\mathrm{x}$ titik posisi berdiri alat

$\mathrm{Yi}=$ Koordinat y titik posisi berdiri alat

$\mathrm{Xf}=$ Koordinat $\mathrm{x}$ titik posisi target forsight

$\mathrm{Yf}=$ Koordinat $\mathrm{y}$ titik posisi target forsight

$\mathrm{Xb}=$ Koordinat $\mathrm{x}$ titik posisi target backsight

$\mathrm{Yb}=$ Koordinat y titik posisi target backsight

$\mathrm{IF}^{2}=$ Jarak Kuadrat posisi alat dan posisi forsight

$\mathrm{IB}^{2}=$ Jarak Kuadrat posisi alat dan posisi backsight

Penentuan nilai estimasi parameter terbaik menggunakan persamaan sebagai berikut (Leick 2004):

$N=\mathrm{A}^{\mathrm{T}} P A$

$U=\mathrm{A}^{\mathrm{T}} P F$

$X=-\mathrm{N}^{-1} \mathrm{U}$

$X=\mathrm{A}^{\mathrm{T}} P \mathrm{~A}^{-1} \mathrm{~A}^{\mathrm{T}} P F$

Pada pengamatan pengikatan kebelakang dilakukan dengan menggunakan perhitungan collins dan dengan menggunakan hasil perataan Least Square. Kemudian menerapkan prinsip kuadrat-terkecil ke persamaan dengan prasyarat pengamatan yang diestimasi oleh matriks bobot mengarah ke sekumpulan persamaan normal bentuk (Deakin 2005): 
$\left(B^{\mathrm{T}} \mathrm{WB}\right) \mathrm{x}=\mathrm{B}^{\mathrm{T}} \mathrm{Wf}$

$\mathrm{N} \mathrm{x}=\mathrm{t}$

$\mathrm{x}=\mathrm{N}^{-1} \cdot \mathrm{t}$

Keterangan:

$\mathrm{B} \quad=$ matriks koefisien yang berisi koefisien arah dan sudut. (nxu)

$\mathrm{W} \quad=$ matriks bobot (nxn)

$\mathrm{f}=$ adalah vector $(\mathrm{nx} 1)$ istilah numerik yang "sudut azimuth hitungan - sudut azimth pengamatan"

$\mathrm{x} \quad=$ parameter residual $(\mathrm{nx} 1)$

Pada pembentukan matriks $\mathrm{B}, \mathrm{W}, \mathrm{f}, \mathrm{x}$, dibentuk dengan parameter dan komponen sebagai berikut (Deakin 2005):

$\mathrm{B}=\left[\begin{array}{lll}a_{1} & b_{1} & 1 \\ a_{2} & b_{2} & 1 \\ a_{n} & b_{n} & 1\end{array}\right]$

$\mathrm{W}=\left[\begin{array}{ccc}1 / S_{1}{ }^{2} & 0 & 0 \\ 0 & 1 / S_{2}{ }^{2} & 0 \\ 0 & 0 & 1 / S_{n}{ }^{2}\end{array}\right]$

$\mathrm{f}=\left[\begin{array}{c}\varphi 1-\left(\alpha 1+z^{\circ}\right) \\ \varphi 2-\left(\alpha 2+z^{\circ}\right) \\ \varphi n-\left(\alpha n+z^{\circ}\right)\end{array}\right]$

$\mathrm{x}=\left[\begin{array}{c}\Delta E \\ \Delta N \\ \Delta z\end{array}\right]$

$a_{1}=\frac{-(E k-E p)}{S k^{2}} ; b_{1}=\frac{N k-N p}{S k^{2}}$

Dimana:

$\mathrm{E}_{\mathrm{k}} \quad=$ Koordinat Easting posisi yang diketahui

$\mathrm{E}_{\mathrm{p}} \quad=$ Koordinat Easting posisi koordinat bantuan resection

$\mathrm{N}_{\mathrm{k}} \quad=$ Koordinat Norhting posisi yang diketahui

$\mathrm{N}_{\mathrm{p}} \quad=$ Koordinat Norhtin posisi koordinat bantuan resection

$\varphi \quad=$ sudut azimuth terhadap titik resection.

$\mathrm{S}_{\mathrm{k}} \quad=$ Jarak antara kedua titik $(\mathrm{m})$

Setelah dilakukan perhitungan dengan 2 metode pengamatan tersebut dilakukan analisa data dengan perbandingan selisih dan nilai $R M S E$ antara koordinat acuan pada PT. bumi Sukses indo dengan koordinat hasil perhitungan dengan menggunakan 2 metode pengaamatan tersebut. Dan diapatkan nilai RMSE dari proses pembagian antara nilai akar kuadrat total selisih ukuran kuadrat dengan jumlah ukuran yang digunakan (Harvey 2006). Rumus menghitung RMSE disajikan pada persamaan

$R M S E=\frac{\sqrt{\Sigma(\mathrm{R}-\mathrm{R} 1)^{2}}}{n}$

Dimana:

RMSE : Root Mean Square Error

$\mathrm{R} \quad$ : Nilai yang dianggap benar

R1 : Nilai hasil ukuran 


\section{Hasil dan Pembahasan}

Pada penelitian ini didapatkan nilai koordinat acuan dari PT. Bumi Suksesindo sebagai nilai kooordinat pembanding antara koordinat-koordinat hasil perhitungan dengan metode pengamatan poligon tertutup dengan metode pengikatan kebelakang. Koordinat acuan ditampilkan dalam tabel berikut:

Tabel 1. Koordinat titik Wall Station objek pengamatan

\begin{tabular}{ccc}
\hline $\begin{array}{c}\text { Titik } \\
\text { Wall Station }\end{array}$ & $\begin{array}{c}\text { Easting } \\
(\mathrm{m})\end{array}$ & $\begin{array}{c}\text { Northing } \\
(\mathrm{m})\end{array}$ \\
\hline DC1-18 & 175079,612 & 9045367,811 \\
DC1-20 & 175031,582 & 9045370,098 \\
DC1-25 & 175014,156 & 9045366,673 \\
DC1-42 & 174592,914 & 9045804,126 \\
DC1-46 & 174543,532 & 9045861,241 \\
DC1-48 & 174512,947 & 9045896,861 \\
\hline
\end{tabular}

Berikut merupakan ploting untuk bentuk poligon pada pengamatan poligon Box Cut pada penelitian ini.

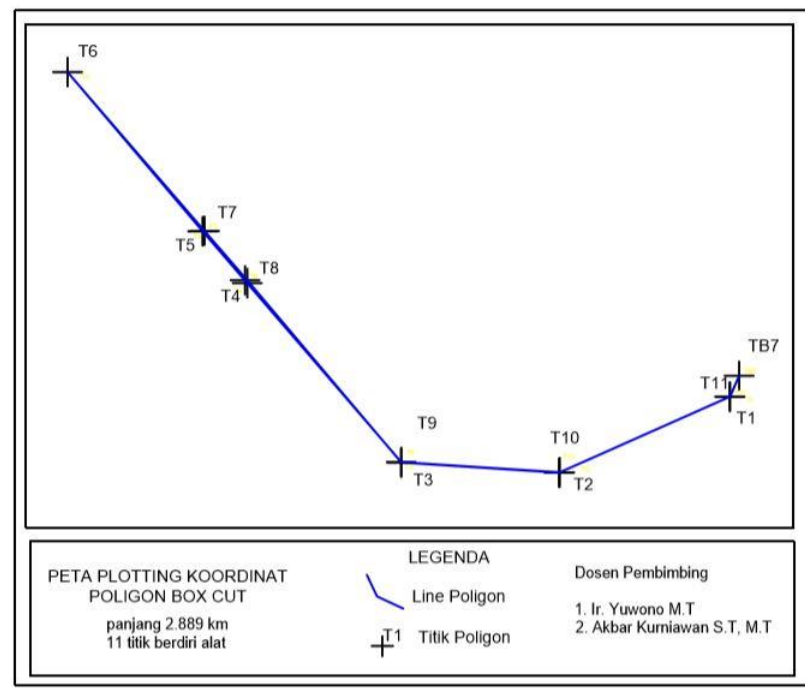

Gambar 5. Desain Poligon Box Cut

Perhitungan Least Square atau perhitungan Kuadrat terkecil merupakan perhitungan titik koordinat dengan koreksi paling minimum dan Dilakukan iterasi sehingga didapatkan nilai error paling terkecil. Berikut merupakan perhitungan dari perhitungan Least Square. Pada perhitungan ini dilakukan dan didapatkan dari hasil iterasi yang ke 3. Dengan hasil koordinat kerangka poligon seperti berikut:

Tabel 2. Hasil Koordinat titik Wall astation dengan menggunakan pengamatan Poligon tertutup dengan perataan Least Square

\begin{tabular}{ccc}
\hline \multicolumn{3}{c}{ Koordinat Wall Station } \\
\hline Point & Easting $(m)$ & Northing $(m)$ \\
\hline DC1 42 & 174592,92 & 9045804,14 \\
DC1 46 & 174543,53 & 9045861,25 \\
\hline
\end{tabular}




\begin{tabular}{lcc}
\hline DC1 48 & 174512,95 & 9045896,88 \\
DC1 18 & 175079,610 & 9045367,810 \\
DC1 20 & 175031,580 & 9045370,101 \\
DC1 25 & 175014,154 & 9045366,675 \\
\hline
\end{tabular}

Pengambilan data dilakukan dengan menggunakan Total Station TS16 dengan prinsip pengikatan kebelakang, pada koordinat titik kontrol Wall Station yang akan dicari dengan titik kontrol yang telah ada. Pada perhitungan ini akan dilakukan pertaan pengikatan kebelakang dengan menggunakan data dan koordinat hasil olahan koordinat. Dengan menghasilkan nilai titik koordinat Wall Station sebagai berikut:

Tabel 3. Hasil Koordinat pada titik Wall Station dengan pengamatan pengikatan kebelakang dengan perataan Least Square

\begin{tabular}{ccc}
\hline $\begin{array}{c}\text { Titik } \\
\text { Wall Station }\end{array}$ & $\begin{array}{c}\text { Easting } \\
(\mathrm{m})\end{array}$ & $\begin{array}{c}\text { Northing } \\
(\mathrm{m})\end{array}$ \\
\hline DC1-18 & 175079,608 & 9045367,790 \\
DC1-20 & 175031,577 & 9045370,083 \\
DC1-25 & 175014,150 & 9045366,64 \\
DC1-42 & 174592,919 & 9045804,128 \\
DC1-46 & 174543,5039 & 9045861,245 \\
DC1-48 & 174512,950 & 9045896,870 \\
\hline
\end{tabular}

Setelah didapatkan nilai titik koordinat masing masing titik koordinat Wall Station, akan dihitung perbandingan selisih nilai koordinat dan perhitungan nilai RMSE pada masing masing nilai koordinat Wall Station. Dan didapatkan hasil sebagai berikut:

Tabel 4. Nilai selesih Koordinat titik Wall Station dengan pengamatan Poligon tertutup dengan nilai Koordinat acuan

\begin{tabular}{ccc}
\hline \multicolumn{3}{c}{ Least Square } \\
\hline Titik & Easting $(m)$ & Northing $(m)$ \\
\hline DC1-42 & $-0,003$ & 0,005 \\
DC1-46 & $-0,005$ & 0,004 \\
DC1-48 & $-0,004$ & 0,004 \\
DC1-18 & 0,000 & 0,001 \\
DC1-20 & 0,001 & 0,003 \\
DC1-25 & 0,000 & 0,002 \\
\hline
\end{tabular}

Tabel 5. Nilai selesih Koordinat titik Wall Station dengan pengamatan pengikatan kebelakang dengan nilai Koordinat acuan

\begin{tabular}{ccc}
\hline \multicolumn{3}{c}{ Pengikatan Kebelakang } \\
\hline Titik & Easting $(m)$ & Northing $(m)$ \\
\hline DC1-42 & $-0,001$ & $-0,008$ \\
DC1-46 & 0,001 & $-0,006$ \\
DC1-48 & $-0,001$ & $-0,005$ \\
DC1-18 & $-0,002$ & $-0,019$ \\
DC1-20 & $-0,002$ & $-0,015$ \\
\hline
\end{tabular}




\begin{tabular}{lll}
\hline DC1-25 & $-0,004$ & $-0,024$ \\
\hline
\end{tabular}

Pada penelitian ini juga dighitung niali masing masing niali RMSE anatara kedua metode pengamatan dan kedua metode perhitungan dengan kooridnat acuan sebagai nialai R1/ Niali yang dianggap benar. Dan diapatkan hasil sebagai berikut :

Tabel 6. Perhitungan nilai RMSE pada masing masing Koordinat

\begin{tabular}{ccc}
\hline $\begin{array}{c}\text { Nama } \\
\text { point }\end{array}$ & Poligon Tertutup & $\begin{array}{c}\text { Pengikatan } \\
\text { Kebelakang }\end{array}$ \\
\hline DC142 & 0.00315 & 0.00403 \\
DC146 & 0.00320 & 0.00403 \\
DC148 & 0.00288 & 0.00450 \\
DC118 & 0.00031 & 0.00955 \\
DC120 & 0.00144 & 0.00757 \\
DC125 & 0.00113 & 0.01217 \\
\hline
\end{tabular}

\section{Kesimpulan}

Berdasarkan pada penelitian yang telah dilakukan dapat disimpulkan bahwa: Dari perhitungan RMSE didapatkan nilai koordinat yang memiliki error terkecil dengan metode pengamatan Poligon tertutup dengan perhitungan Least Square pada Poligon Box Cut.pada semua point wall station. DC1 -18 dengan nilai error 0,00031 m, DC1 -20 dengan nilai error 0,00144 m, DC1 -25 dengan nilai error 0,00113 m, DC1 -42 dengan nilai error 0,00315 m, DC1 -46 dengan nilai error 0,00320 m, DC1 -48 dengan nilai error 0,00288 m. Hal ini dikarenakan pada perhitungan dengan menggunakan metode least square dengan penggunaan data paling terbaru yaitu tahun 2020 menghasilkan nilai dengan kesalahan terkecil dan mendekati dengan nilai koordinat acuan yang digunakan.

Kesalahan yang mempengaruhi adanya perbedaan anatara kedua metode tersebut adalah pada pengamatan poligon dilakaukan dengan koreksi, serta perhitungan toleransi, faktor lain seperti jarak dan sudut yang harus andil dalam pengamatan sehingga akan terbentuk koordinat yang lebih baik. Akan tetapi pada perhitungan dengan menggunakan metode pengikatan kebelakang dilakukan tanpa adanya toleransi, koreksi dan faktor faktor yang harus perhitungkan sebelumnya.

Metode yang tepat digunakan dalam pengamatan posisi dalam tambang bawah tanah adalah metode pengamatan Poligon Tertutup dengan metode perhitungan Least Square

\section{Ucapan Terimakasih}

Penulis. mengucapkan terima kasih kepada PT. Bumi Suksesindo beserta Decline Departmen yang telah memberikan fasilitas, pengarahan dan batuan dalam mendapatakan data sehingga pelaksanaan penelitian dapat berjalan dengan lancar.

\section{Daftar Pustaka}

Anonim, 2017. Pt. Bumisukses Indo. Banyuwangi, Jawa Timur. https://bumisuksesindo.com/ di akses pada tanggal 12 Desember 2019 pada pukul 13.45 WIB.

Amir, Zulfahmi. 1998. Dasar-dasar Pengukuran Terristris dan Pemetaan Situasi. Padang. Universitas Andalas

Asshiddiqie, Jimly, Konstitusi Ekonomi, (Jakarta: Penerbit Buku Kompas, 2010), Hal. 281

Atlas Copco. 2007. Minning Methods in Underground Mining. Second edition 2007. www.atlascopco.com

Basuki, S. 2006. Ilmu Ukur Tanah. Yogyakarta: Universitas Gadjah Mada Press. 
Basuki B. Prunomo, 2011, Dasar-Dasar Urologi, Perpustakaan Nasional RI, Katalog Dalam Terbitan (KTO) Jakarta.

Burnside, C.D, 1987, Electrics Distance Measurement, Second Edition, Blocksburg, Virginia, London.

Brinker, R. C., Wolf, P. R., Elfick, M., \& Fryer, J. G. (1984). Elementary surveying. Harper \& Row New York

Frick, Heinz, 1979, "Mekanika Teknik Statika dan Kegunaannya “, Kanisius, Yogyakarta

Ghilani, Charles D, 2010. Adjustment Computation Spatial Data Analysis fifith edition. John Wiley \& Sons, Inc. Hoboken New Jersey, Canada

Hamrin, H, 1980, Underground Mining Methods and Applications. Atlas Copco, Stockholm, Sweden

Harvey, Bruce R. 2006. Practical Least Squares: And Statistics for Surveyors. New South Wales: School of Surveying and Spatial Information Systems.

Hendriatinigsih, S. 1979. Geomteris Jalan Raya dan Stake Out.Departemen Geodesi FTSP - ITB: Bandung.

Hidayat, Wahyu, 2014. Dampak Sektor Pertambangan Terhadap PerekonomianWilayah di Kabupaten Luwu Timur. Bogor. Jurnal Economia, Volume 10, Nomor 1,April 2014. Institut Pertanian Bogor, Indonesia

Irvine, W., 1974.,Surveying for Construction, Mc.graw-Hill Book Company United

Leick, A., 2004, “GPS Satellite Surveying”, third edition, John Wiley \& Sons, Inc., Hoboken New Jersey.

Muda, I, 2008. Teknik Survei dan Pemetaan Jilid 2 . Jakarta: Direktorat Pembinaan Sekolah Menengah Kejuruan

Mulkan, S.F.,Sumaryanto, E.,Ilmu Ukur Tanah Wilayah, Departemen Pendidikan dan Kebudayaan, Direktorat Pendidikan Menengah Kejuruan, 1980

Nurjati, C. 2004. Modul Ajar Ilmu Ukur Tanah. Program Studi Teknik Geodesi. Institut Teknologi Sepuluh Nopember Surabaya

Paul R. Wolf dan Charles D. Ghilani. 2002. Elementary Surveying an Introducing to Geomatics. New Jersey: Prentice Hall.

Purwohardjo, U. U. 1986. Ilmu Ukur Tanah seri A. Bandung: Institut Teknologi Bandung.

R.E. Deakin, 2005, Geospatial Science Notes On Least Square, School of Mathematical and Geospatial Sciences, RMIT University

Schofield, W., and M. Breach., 2007, Engineering Surveying Sixth edition, Taylor \& Francis group, USA

Sinaga, Indra. 1991. Surveyor Indonesia di Persimpangan Jalan 1991. Makalah Seminar "Profesi Surveyor dalam Era Teknologi Geoinformatika", Kongres ke-7 Ikatan Surveyor'Indonesia di kampus UGM Yogyakarta 13-14 Desember 1991.

Soeta'at. 1994. Hubungan Distorsi Kamera Dalam Bentuk Tabel dengan Bentuk Polinomial. Jurusan Teknik Geodesi Fakultas Teknik Universitas Gadjah Mada. Yogyakarta

Supratman, Odih 2018. Modul 2: Penambangan Bawah Tanah. No Kode: DAR2/Profesional/001/2018. PPG DALAM JABATAN KEMENTERIAN RISET: TEKNOLOGI DAN PENDIDIKAN TINGGI.

Tribhuwana, Awliya. 2018. Perbandingan Pengukuran Luas Area antara Theodolit dan Global Positioning System (GPS). LOGIKA, Desember 2018, XXII (3):58-64. Cirebon: Universitas Swadaya Gunung Jati

Wongsotjitro, Soetomo 2008, Ilmu Ukur Tanah, Kanisius, Yogyakarta

Wongsotjitro, S., 1977, Ilmu Ukur Tanah, Yayasan Kanisius, Yogyakarta.

This article is licensed under a Creative Commons Attribution-ShareAlike 4.0 International License. 